\title{
Ocimum gratissimum Linn. Leaves reduce the key enzymes activities relevant to erectile dysfunction in isolated penile and testicular tissues of rats
}

\author{
Oluwafemi Adeleke Ojo ${ }^{1,2^{*}}$ (D) Adebola Busola Ojo ${ }^{3}$, Babatunji Emmanuel Oyinloye ${ }^{1,6}$, Basiru Olaitan Ajiboye ${ }^{1}$, \\ Omosola Olufisayo Anifowose ${ }^{4}$, Ayodeji Akawa ${ }^{5}$, Oluranti Esther Olaiya ${ }^{5}$, Oluwaseun Ruth Olasehinde ${ }^{5}$ and \\ Abidemi Paul Kappo ${ }^{6}$
}

\begin{abstract}
Background: Ocimum gratissimum L. is a medicinal plant widely grown in tropical and subtropical regions with the leaf decoction usually taken in folk medicine to enhance erectile performance in men although the probable mechanism of actions remains undetermined. This study examined the inhibitory potentials of Ocimum gratissimum leaves on some key enzymes associated with erectile dysfunction in penile and testicular tissues of the rat.

Methods: Inhibitory effect of aqueous extract (1:10 W/V) of 0 . gratissimum leaves on the activities of phosphodiesterase- 5 (PDE-5), arginase, angiotensin I-converting enzyme (ACE), and acetylcholinesterase (AChE) in penile and testicular tissues were assessed. Also, the extract was investigated for ferric reducing antioxidant property(FRAP) and 1,1-diphenyl-2-picrylhydrazil (DPPH) radical scavenging abilities.
\end{abstract}

Results: The extract showed higher PDE-5 $\left(I C_{50}=43.19 \mu \mathrm{g} / \mathrm{mL}\right), A C E\left(I C_{50}=44.23 \mu \mathrm{g} / \mathrm{mL}\right), A C h E\left(I C_{50}=55.51 \mu \mathrm{g} / \mathrm{mL}\right)$ and arginase $\left(I C_{50}=46.12 \mu \mathrm{g} / \mathrm{mL}\right)$ inhibitory activity in the penile tissue than PDE-5 $\left(I C_{50}=44.67 \mu \mathrm{g} / \mathrm{mL}\right), A C E\left(I C_{50}=53.99 \mu \mathrm{g} /\right.$ $\mathrm{mL}), A C h E\left(I C_{50}=60.03 \mu \mathrm{g} / \mathrm{mL}\right)$ and arginase $\left(I C_{50}=49.12 \mu \mathrm{g} / \mathrm{mL}\right)$ inhibitory activity in the testicular tissue homogenate. Furthermore, the extract scavenged free radicals and in a dose-dependent manner.

Conclusion: The enzyme activities displayed might be associated with the bioactive compounds present in the extract which could possibly explain its use in the management of erectile dysfunction (ED).

Keywords: Erectile dysfunction, Angiotensin I -converting enzyme (ACE), Phosphodiesterase-5 (PDE-5), Acetylcholinesterase (AChE), Arginase, Ocimum gratissimum

\section{Background}

The occurrence of erection involves the neuronal, vascular, endocrine and local secretory interplay. The processes involved are blood vessel dilation, trabecular smooth muscle relaxation, and activation of the veno-occlusive mechanism of the corpus carvenosum and spongiosum tissues [1]. Erectile dysfunction (ED) is the inability to achieve and maintain penile tumescence adequate for the suitable erotic act [2]. It occurs as a

\footnotetext{
* Correspondence: oluwafemiadeleke08@gmail.com

${ }^{1}$ Department of Biochemistry, Afe Babalola University, Ado-Ekiti, Nigeria

${ }^{2}$ Department of Biochemistry, University of Ilorin, Ilorin, Nigeria

Full list of author information is available at the end of the article
}

result of the decrease in bioavailability of nitric oxide (NO) due to decreased expression of endothelial tissue nitric oxide synthase (NOS) activity and/or increased elimination of NO [3]. However, NOS and arginase vie for L-arginine as a substrate in cells. In the urea cycle, $\mathrm{L}$-arginine is converted to ornithine and urea and the conversion is catalyzed by the enzyme arginase [4]. The fast hydrolysis of secondary messengers such as cyclic adenosine monophosphate (cAMP) and cyclic guanosine monophosphate (cGMP) have been linked to pathologies like ED [5]. Cyclic nucleotide phosphodiesterase (PDE) enzymes regulate the cytosolic levels of secondary messengers $[4,6]$. Predominantly in the smooth muscle of

(c) The Author(s). 2019 Open Access This article is distributed under the terms of the Creative Commons Attribution 4.0 International License (http://creativecommons.org/licenses/by/4.0/), which permits unrestricted use, distribution, and reproduction in any medium, provided you give appropriate credit to the original author(s) and the source, provide a link to the Creative Commons license, and indicate if changes were made. The Creative Commons Public Domain Dedication waiver (http://creativecommons.org/publicdomain/zero/1.0/) applies to the data made available in this article, unless otherwise stated. 
corpora cavernosum is phosphodiesterase type-5. Hence, the mitigation of phosphodiesterase-5 (PDE-5) can also be a therapeutic approach in the management of ED [6]. Additionally, acetylcholinesterase (AChE) inhibition is an alternative technique for managing $\mathrm{ED}$ because it controls the levels of acetylcholine [7]. Moreover, the increasing AChE activity decreases the level of acetylcholine on conversion to its products acetate and choline $[8$, 9]. Earlier studies reported that inhibition of AChE can increase the level of acetylcholine thereby improving erection $[10,11]$. Moreover, the renin-angiotensin system (RAS) is also a key aspect in the development of erectile dysfunction. Increase in the angiotensin-I converting enzyme (ACE) caused by erectile dysfunction simultaneously leads to the generation of angiotensin-II [12-14]. Hence, ACE activity inhibition leads to an increase in erectile performance and a significant reduction of angiotensin-II levels in patients with ED [15]. Oxidative stress-induced ED occurs when reactive oxygen species such as superoxide anion $\left(\mathrm{O}_{2}^{-}\right)$reacting with nitric oxide gas, forms peroxynitrite $\left(\mathrm{ONOO}_{2}\right)$ and reduces the biological presence of $\mathrm{NO}$ [16]. Adequate intake of natural plant products may protect against oxidative stress and reduce the chance of developing several diseases like male sexual dysfunction [17]. Furthermore, the management of ED with conventional medicine is connected with adverse side effects and toxicities. Thus, the need to continuously explore medicinal plants with sexual enhancing properties may serve as a cheap and safe alternative therapy [18].

Ocimum gratissimum (OG) is a perennial herb that belongs to the family Lamiaceae. It is thought to originate from Asia and Africa [19]. In Nigeria and other parts of the world, it is used as a traditional vegetable condiment and oral care products. Furthermore, OG had been shown to possess numerous pharmacological properties hence its use in traditional or alternative medicine. These properties include antioxidant [20-24]; anti-anemic [25]; antidiarrhoeal [26] and protective effects on hepato-renal indices [27]. In a study conducted by Iweala and Obidoa [29], using Ocimum gratissimum-supplemented diet (OGSD), rats fed with OGSD for 6 months showed an increased number of spermatozoa suggesting the capacity of OG to enhance reproductive ability [28]. Another study conducted by Pande and Pathak [29] revealed that ethanolic extract of OG, significantly increased the sexual behaviors of normal male albino mice at a dose of 100, 250, and 500 $\mathrm{mg} / \mathrm{kg}$ body weight for 7 days with $500 \mathrm{mg} / \mathrm{kg}$ having the most noticeable effect, without any gastric ulceration and adverse effects [29, 30]. In addition to this, Ebong et al. [31] reported that combined extracts of Moringa oleifera and Ocimum gratissimum had better ameliorative effects on testicular architecture and spermatogenesis after 28 days of treatment than Moringa extract alone in diabetic rats. According to the authors, a combination of the two plant extracts thus provides a cheap alternative to treating diabetes-associated testicular damage and sexual dysfunction [31]. The plant leaf extract is used in alternative medicine for the management of erectile dysfunction [31]. However, there is limited information on the possible mechanisms of actions of O. gratissimum on the penile and testicular function. Thus, this study investigated the inhibitory effects of aqueous extract from $O$. gratissimum leaves on enzymes such as (phosphodiesterase-5 (PDE-5), angiotensin-1 converting enzyme (ACE), acetylcholinesterase (AChE), and arginase) relevant to ED in penile and testicular tissue homogenates. Antioxidant activity (ferric reducing antioxidant property (FRAP) and 1,1-diphenyl-2-picryl-hydrazil (DPPH)) of the leaves were also examined.

\section{Methods}

\section{Plant collection}

O. gratissimum leaves were bought from a King's market, Ado-Ekiti in November 2017. It was authenticated by Mr. Omotayo with herbarium number (UHAE 15) and deposited at the Department of Plant Science, Ekiti State University, Ado-Ekiti, Nigeria. The Ocimum gratissimum leaves were dried and pulverized using a blender. The powder obtained weighing $70 \mathrm{~g}$ was macerated in 700 $\mathrm{mL}$ of distilled water for $24 \mathrm{~h}$ at room temperature as described by [32]. It was then filtered and the resulting filtrate was concentrated on a steam bath to give a yield of $40.45 \mathrm{~g}$ of the residue.

\section{Chemicals and reagents}

Chemicals such as acetylthiocholine iodide, 5,5' -dithio-bis (2- nitrobenzoic acid) (DTNB), thiobarbituric acid (TBA), trichloroacetic acid (TCA), and 1,1-diphenyl-2 picrylhydrazyl (DPPH) were sourced from Sigma-Aldrich, Chemie $\mathrm{GmbH}$ (Steinheim, Germany). Acetic acid was procured from BDH Chemical Ltd., (Poole, England). A Jenway UV-visible spectrophotometer (Model 6305; Jenway, Barlo World Scientific, Dunmow, United Kingdom) was used to measure absorbance.

\section{Handling of experimental animals}

Twenty adult male Wistar albino rats (weighing between $290 \pm 5 \mathrm{~g}$ ) of about 10-14 weeks old were obtained from Animal breeding house of Afe Babalola University and five [5] rats were used for each of the assays carried out. They were handled in accordance with the guide for Care and Use of Laboratory Animals formulated by the National Academy of Science, issued by the National Institute of Health (USA). The ethical guidelines were followed in accordance with National and Institutional guidelines for the protection of animal welfare during the experiments. The study was approved by Afe Babalola University ethical 
review committee (ABUERC) with reference number 17/ ABUAD/066. The rats were allowed to acclimatize for 2 weeks and maintained at room temperature under laboratory conditions ( $12 \mathrm{~h}$ light/dark cycle) with access to rat chow and water ad libitum.

\section{Preparation of penile and testicular tissue homogenate} Experiment animals were placed under ether anesthesia and euthanized by cervical dislocation, then tissue samples were collected. Penis and testes were removed, washed, bottled dry and weighed. These tissues were homogenized in cold saline $(1 / 10 \mathrm{w} / \mathrm{v})$ at approximately $1200 \mathrm{rpm}$ in a homogenizer for $10 \mathrm{~min}$ at $3000 \mathrm{rpm}$. The supernatant was collected and used for the inhibitory enzyme activity assay.

\section{Phosphodiesterase-5 (PDE-5) inhibitory activity}

The ability of the extracts to inhibit PDE-5 activity was evaluated by [33]. The assay solution containing $5 \mathrm{mM}$ of the substrate (p-nitrophenyl phenyl phosphonate), $100 \mu \mathrm{l}$ of tissue (penile and testicular) supernatant, 20 $\mathrm{mM}$ Tris-HCL $(\mathrm{pH} 8.0)$ and the aqueous extracts of $O$. gratissimum $(20-100 \mu \mathrm{g} / \mathrm{ml})$ were incubated at $37^{\circ} \mathrm{C}$ for $10 \mathrm{~min}$. The amount of p-nitrophenol produced was read as a change in absorbance after $5 \mathrm{~min}$ at $400 \mathrm{~nm}$. The control experiment was performed without the extracts and sildenafil. PDE-5 inhibitory enzyme activity was expressed as percentage inhibition:

$P D E-5$ inhibition $(\%)=\left[\left(\mathrm{Abs}_{\text {control }}-\mathrm{Abs}_{\text {samples }}\right) / \mathrm{Abs}_{\text {control }}\right] \times 100$

where Abs control is the absorbance without the extract and Abs samples are the absorbance with extract.

\section{Arginase inhibitory activity}

The penis and testicular homogenates were prepared by homogenizing $10 \mathrm{~g}(w / v)$ of penile and testicular tissue in cold buffer (phosphate buffer, $\mathrm{pH}$ 7.2). The homogenized tissue samples were centrifuged for $20 \mathrm{~min}$ at $4000 \mathrm{rpm}$ and the supernatant was used as the source of enzyme. The activity of arginase was estimated by the amount of urea produced via Ehrlich's reagent. The solution comprised in final volume $1.0 \mathrm{mM}$ Tris- $\mathrm{HCl}$ buffer $\mathrm{pH}$ 9.5, $1.0 \mathrm{mM} \mathrm{MnCl}, 0.1 \mathrm{M}$ arginine solution, an aqueous extract of $O$. gratissimum $(20-100 \mu \mathrm{g} / \mathrm{ml}) / \mathrm{L}-2$-amino-[4-(20-hydroxyguanidino)] butyric acid (LNOHA) which was made up to $1.0 \mathrm{~mL}$. The solution was incubated for $10 \mathrm{~min}$ at $37^{\circ} \mathrm{C}$ and stopped by adding $2.5 \mathrm{~mL}$ Ehrlich reagent ( $2.0 \mathrm{~g}$ of p-dimethyl amino benzaldehyde in $20 \mathrm{~mL}$ of concentrated hydrochloric acid and made up to $100 \mathrm{~mL}$ with distilled water). Absorbance was read after $20 \mathrm{~min}$ at $450 \mathrm{~nm}$. The control experiment was performed without the test sample or standard and arginase inhibitory activity was calculated as percentage inhibition [34].

\section{Acetylcholinesterase activity assay}

Penile and testicular tissue samples were homogenized in cold phosphate buffer $0.1 \mathrm{M}, \mathrm{pH} 7.2$ and were used as the source of AChE enzyme. The inhibitory effect of the aqueous extracts of $O$. gratissmum $(20-100 \mu \mathrm{g} / \mathrm{ml})$ and standard drug prostigmine on AChE activity was evaluated as described by [8] with slight modifications. AChE activity was estimated in a solution containing $200 \mu \mathrm{L}$ tissue homogenate, $100 \mu \mathrm{L}$ of 5,5-dithiol-bis (2-nitrobenzoic) acid (DTNB $3.3 \mathrm{mM}$, in $0.1 \mathrm{M}$ phosphate buffered solution, pH 7.0, containing $6 \mathrm{mM} \mathrm{NaHCO}$ ), aqueous extracts of $O$. gratissmum. This was incubated for $20 \mathrm{~min}$ at $25^{\circ} \mathrm{C}$, and acetylthiocholine iodide was added. The absorbance of the enzyme activity was read at $412 \mathrm{~nm}$. AChE activity was expressed as percentage inhibition [1].

Angiotensin-I-converting enzyme (ACE) inhibitory activity Inhibition of the ACE activity of aqueous extracts of $O$. gratissmum was determined according to the described protocol of [35]. Varying concentrations of the aqueous extract $(20-100 \mu \mathrm{g} / \mathrm{ml})$ and standard drug lisinopril and $50 \mu \mathrm{L}$ of homogenate from penile and testicular tissues as a source of ACE enzyme $(4 \mathrm{mU} / \mathrm{mL})$ were pre-incubated at $37^{\circ} \mathrm{C}$ for $15 \mathrm{~min}$. Thereafter, the enzymatic process was started by adding $200 \mu \mathrm{L}$ of 8.33 mM ACE substrate [hippuryl-l-histidyl-l-leucine (HHL)] in $125 \mathrm{mM}$ of Tris- $\mathrm{HCl}$ buffer ( $\mathrm{pH} \mathrm{8.3)} \mathrm{to} \mathrm{the} \mathrm{solution}$ and incubated at $37^{\circ} \mathrm{C}$ for $30 \mathrm{~min}$. The reaction was terminated by adding $300 \mu \mathrm{L}$ of $1 \mathrm{M} \mathrm{HCl}$. The hippuric acid (Bz-Gly) generated by the reaction was removed with $2 \mathrm{~mL}$ ethyl acetate and further centrifuged to separate the ethyl acetate layer, it was later transferred to a volumetric flask and evaporated to dryness. The obtained residue was reconstituted in distilled water and its absorbance was read at $228 \mathrm{~nm}$. The control experiment was done without the aqueous extract or standard drug lisinopril. ACE percentage inhibition was then calculated in Eq. (1).

\section{Determination of antioxidant activities Ferric reducing antioxidant ability}

Reducing power of the aqueous extract was evaluated via reduction of the $\mathrm{FeCl}_{3}$ solution by [36]. $3 \mathrm{~mL}$ of the extract $(20-100 \mu \mathrm{g} / \mathrm{ml})$ was added to $3 \mathrm{~mL}$ of $200 \mathrm{mM}$ sodium phosphate buffer ( $\mathrm{pH} 6.6)$ and $3 \mathrm{~mL}$ of $1 \%$ potassium ferricyanide. The solution was incubated for 20 $\min$ at $50^{\circ} \mathrm{C}$ in a water bath and $3 \mathrm{~mL}$ of $10 \%$ trichloroacetic acid was used to stop the reaction. The sample was then centrifuged at $650 \mathrm{~g}$ for $10 \mathrm{~min}$ and 5 $\mathrm{mL}$ of the supernatant was added to an equal volume of 
water and $1.0 \mathrm{~mL}, 0.1 \% \mathrm{FeCl}_{3}$. Absorbance was read at $700 \mathrm{~nm}$. Vitamin $\mathrm{C}$ was used as the standard for assessing reducing power and expressed as percentage inhibition.

\section{Free radical scavenging ability}

Free radical scavenging ability of the aqueous extract against DPPH was assessed using the method of [37]. Concisely, suitable dilution of the aqueous extract (20$100 \mu \mathrm{g} / \mathrm{ml}$ ) was added to $1 \mathrm{~mL} 0.4 \mathrm{mM}$ DPPH solution in methanol. The solution was kept in the dark for 30 min and the absorbance was read at $516 \mathrm{~nm}$. DPPH" scavenging ability was estimated with reference to the control and the standard drug used for assessing DPPH activity was vitamin $\mathrm{C}$.

$$
\begin{aligned}
& \mathrm{DPPH}^{*} \text { scavenging ability }(\%) \\
& \quad=\left[\left(\mathrm{Abs}_{\text {control }}-\mathrm{Abs}_{\text {samples }}\right) / \mathrm{Abs}_{\text {control }}\right] \times 100
\end{aligned}
$$

\section{Data analysis}

Data generated were analyzed by one-way analysis of variance (SPSS, Version 20.0, IBM Corporation, NY, USA) one-way ANOVA using Duncan multiple range posthoc test (DMRT). Results are presented as the mean \pm SD in triplicates $(n=3)$. Values were considered to be significantly different at $p<0.05$.

\section{Results}

Phosphodiesterase-5 activities (PDE-5) of aqueous extract of $O$. gratissmum in penile and testicular tissue homogenates were evaluated and presented in Fig. 1. The result showed that the aqueous extract of $O$. gratissmum inhibited PDE-5 enzymes. Taking into consideration the $\mathrm{IC}_{50}$ (lower $\mathrm{IC}_{50}$ value means stronger enzyme inhibition) presented in Table 1, it showed that the extract had a greater inhibitory activity on penile phosphodiesterase-5 $\left(\mathrm{IC}_{50}=43.19 \mu \mathrm{g} / \mathrm{mL}\right)$ than testicular phosphodiesterase-5 $\left(\mathrm{IC}_{50}=44.67 \mu \mathrm{g} / \mathrm{mL}\right)$. Though, sildenafil had the highest activity as shown by the $\mathrm{IC}_{50}(26.65 \mu \mathrm{g} / \mathrm{mL})$.

Arginase inhibitory activity by the aqueous extract of O. gratissmum is displayed in Fig. 2. The extract inhibited arginase activity in a concentration-dependent manner. Though, the $\mathrm{IC}_{50}$ in Table 1 showed that the aqueous extract of $O$. gratissmum had a greater inhibitory activity on penile arginase $(46.12 \mu \mathrm{g} / \mathrm{mL})$ than testicular arginase $(49.12 \mu \mathrm{g} / \mathrm{mL})$. Though, L-NOHA had the highest inhibitory activity as shown by the $\mathrm{IC}_{50}$ $(42.48 \mu \mathrm{g} / \mathrm{mL})$.

Figure 3 showed the result of the inhibitory activity of aqueous extract of O. gratissmum on acetylcholinesterase (AChE) enzyme. AChE activity was inhibited by aqueous extract of $O$. gratissmum as the concentration increases. Hence, aqueous extract of $O$. gratissmum had a better inhibitory activity on penile AChE activity $\left(\mathrm{IC}_{50}=55.51 \mu \mathrm{g} / \mathrm{mL}\right)$ than testicular AChE activity $\left(\mathrm{IC}_{50}=60.03 \mu \mathrm{g} / \mathrm{mL}\right)$ as shown by their $\mathrm{IC}_{50}$ values listed in Table 1.

Figure 4 revealed the inhibition of ACE activity by aqueous extract of $O$. gratissmum in penile and testicular tissue homogenates. ACE activity was inhibited by both the aqueous extract of $O$. gratissmum and lisinopril. However, aqueous extract of $O$. gratissmum had a better

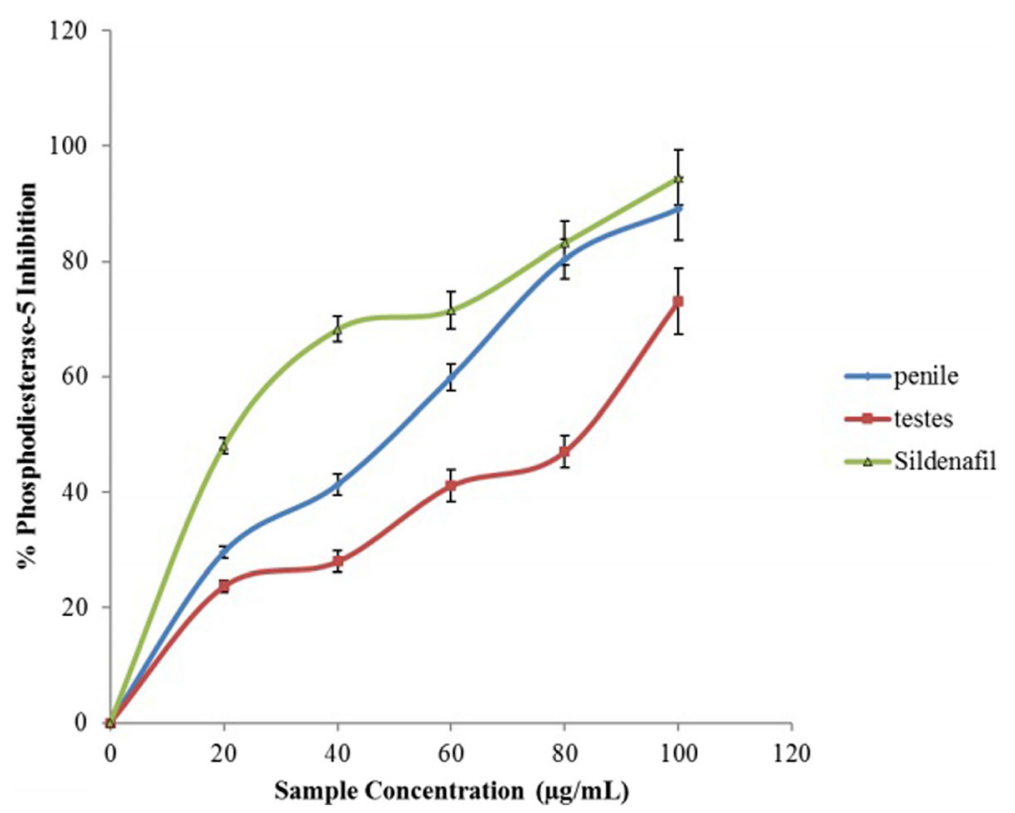

Fig. 1 Inhibition of Phosphodiesterase-5 activity in rats' genitals by aqueous extract from Ocimum gratissimum leaves 
Table $1 \mathrm{IC}_{50}$ values $(\mu \mathrm{g} / \mathrm{mL})$ of ferric reducing power, DPPH, PDE-5, arginase, ACE and AChE inhibitory activities in rat penile and testicular tissue by 0 . gratissimum leaf extracts and standard drugs/inhibitors

\begin{tabular}{|c|c|c|c|c|c|c|}
\hline Sample & PDE-5 $(\mu \mathrm{g} / \mathrm{mL})$ & Arginase $(\mu \mathrm{g} / \mathrm{mL})$ & ACE $(\mu \mathrm{g} / \mathrm{mL})$ & AChE $(\mu \mathrm{g} / \mathrm{mL})$ & FRAP $(\mu \mathrm{g} / \mathrm{mL})$ & $\mathrm{DPPH}(\mu \mathrm{g} / \mathrm{mL})$ \\
\hline Penis & $43.19 \pm 0.02^{c}$ & $46.12 \pm 0.15^{c}$ & $44.23 \pm 0.71^{a}$ & $55.51 \pm 0.45^{\mathrm{a}}$ & - & - \\
\hline Testes & $44.67 \pm 0.01^{b}$ & $49.12 \pm 0.12^{b}$ & $53.99 \pm 0.85^{a}$ & $60.03 \pm 0.34^{\mathrm{a}}$ & - & - \\
\hline Sildenafil $(\mu \mathrm{g} / \mathrm{mL})$ & $26.65 \pm 0.10^{\mathrm{a}}$ & - & - & - & - & - \\
\hline L-NOHA ( $\mu \mathrm{g} / \mathrm{mL})$ & - & $42.48 \pm 0.21^{\mathrm{a}}$ & - & - & - & - \\
\hline Lisinopril ( $\mu \mathrm{g} / \mathrm{mL})$ & - & - & $38.34 \pm 0.01^{\mathrm{a}}$ & - & - & - \\
\hline Prostigmine $(\mu \mathrm{g} / \mathrm{mL})$ & - & - & - & $48.01 \pm 1.02^{\mathrm{a}}$ & - & - \\
\hline Vitamin C $(\mu \mathrm{g} / \mathrm{mL})$ & - & - & - & - & $46.16 \pm 0.51^{\mathrm{a}}$ & $53.81 \pm 0.02^{\mathrm{a}}$ \\
\hline O. gratissimum extract & - & - & - & - & $56.55 \pm 0.78^{a}$ & $69.41 \pm 0.01^{\mathrm{a}}$ \\
\hline
\end{tabular}

Values represent mean \pm standard deviation $(n=3)$. Values with the same superscript along the column are not significant $(p<0.05)$ different. Sildenafil : standard drug for phosphodiesterase-5 (PDE-5); L-NOHA*: standard inhibitor for arginase; prostigmine*: standard drugs for AChE; Lisinopril": standard drug for ACE; Vitamin $C^{*}$ : standard drug for ferric reducing power (FRAP) and DPPH

inhibitory activity on penile than testicular ACE activity as shown by their $\mathrm{IC}_{50}$ values listed in Table 1 .

Figure 5 revealed the ferric reducing ability of the extract. The result revealed that the extracts inhibited ferric reducing power in a concentration-dependent manner. However, vitamin $\mathrm{C}$ was able to reduce the $\mathrm{Fe}^{3+}$ to $\mathrm{Fe}^{2+}$ better than the O. gratissimum extract as revealed by their $\mathrm{IC}_{50}$ values in Table 1 .

Fig. 6 revealed the ability of the leaf aqueous extract of O. gratissmum to scavenge $\mathrm{DPPH}^{-}$in penile and testicular tissues. Aqueous extract of O. gratissmum was able to scavenge DPPH: However, vitamin $\mathrm{C}$ scavenge $\mathrm{DPPH}^{*}$ better than the $O$. gratissimum extract as revealed by their $\mathrm{IC}_{50}$ values in Table 1.

\section{Discussion}

The mechanisms or actions of cGMP are mainly decreased by the phosphodiesterase- 5 enzyme in diverse parts of corpus cavernosum [5]. PDE-5, an important enzyme of the NO/cGMP signaling pathway, that performs a key function in corpus cavernosum weakness, inhibition of nitric oxide-induced cGMP-mediated vasodilation and repairing basal smooth muscle tone and penile detumescence. Thus, the rate of synthesis of cGMP by guanylate cyclase and its degradation by PDEs determines the amount of cGMP within the corpus cavernosum [5]. A protein kinase that decreases cytosolic calcium levels, boosts smooth muscle relaxation leading to penile erection is activated by cGMP $[37,38]$. Sildenafil,

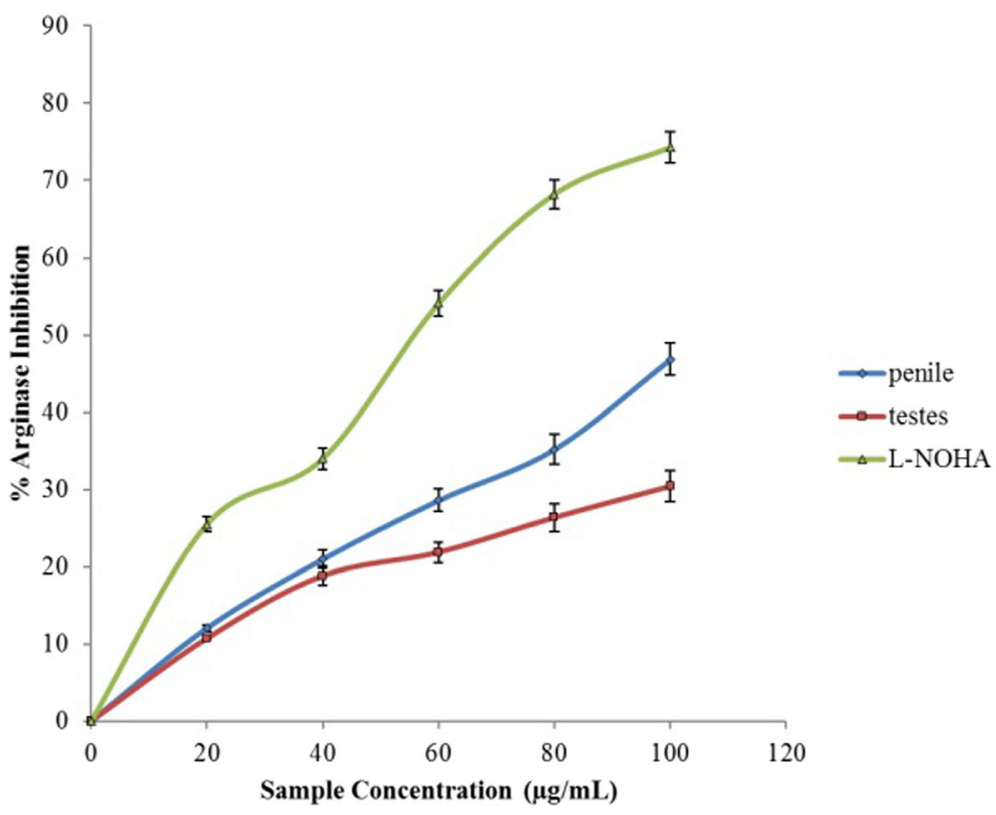

Fig. 2 Inhibition of Arginase activity in rats' genitals by aqueous extract from Ocimum gratissimum leaves 


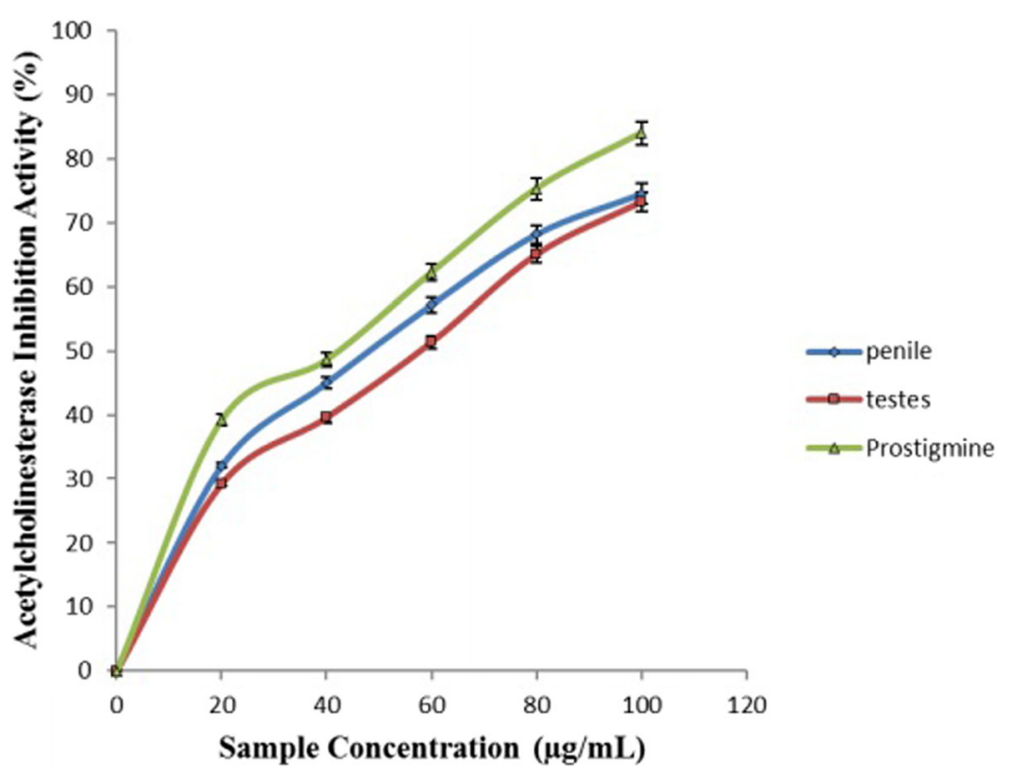

Fig. 3 Inhibition of Acetylcholinesterase activity in rats' genitals by aqueous extract from Ocimum gratissimum leaves

tadalafil, and vardanafil which are PDE-5 inhibitors do not only boost the level of cGMP $[39,40]$ but, likewise, stimulate its activation resulting in the increase of NO leading to the penile erection. However, these PDE-5 inhibitor drugs have other negative effects such as nasal congestion, headache, visual aberrations' dyspepsia, [41]. Furthermore, previous studies have shown that phenolic compounds in plant exhibit PDE-5 inhibition [6, 42, 43]. Hence, the result showed that the extract inhibited PDE-5 activity, this may be due to the presence of phenolic compounds particularly flavonoids, that functions as an endotheliumindependent relaxer [33, 44].
Several studies have previously revealed that nitric oxide production is associated with arginase activity regulation [45]. Current examinations have acknowledged arginase in managing sexual disorders $[46,47]$ leading to upregulation of arginase activity and reduced nitric oxide levels in the penile tissues. In ED, reduced $\mathrm{NO}$ are documented owing to improved arginase activities and changed the expression of endothelial NO synthase (eNOS) [48]. Nevertheless, it is important to note that arginase inhibition by the $O$. gratissimum extracts may possibly be an alternative route of increasing the appearance and activities of eNOS, thus raising the

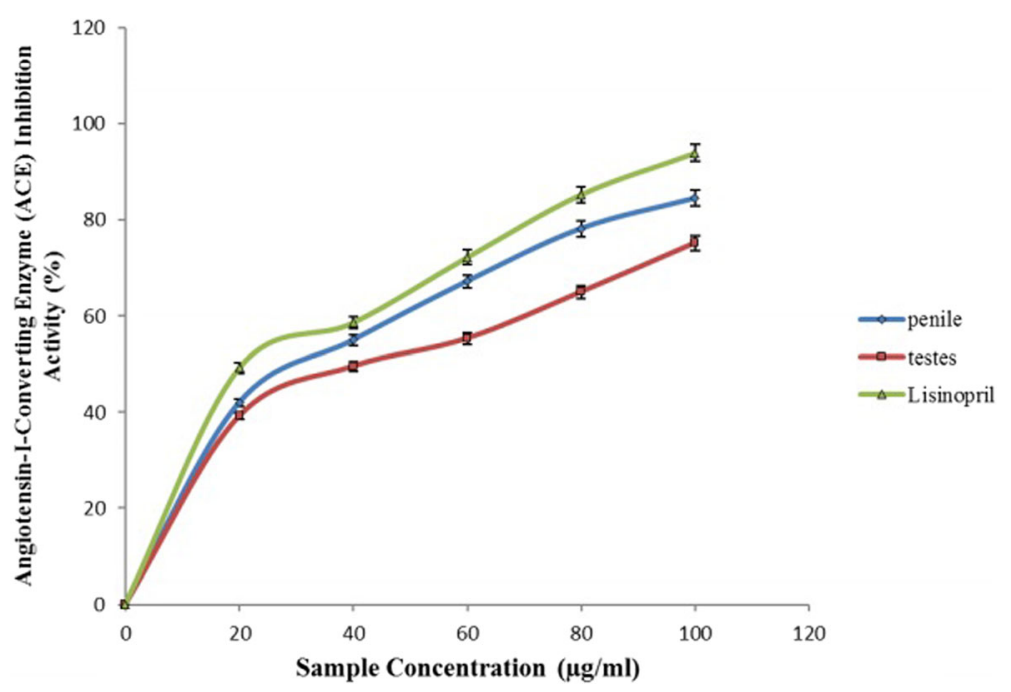

Fig. 4 Inhibition of Angiotensin-l-converting enzyme activity in rats' genitals by aqueous extract from Ocimum gratissimum leaves 


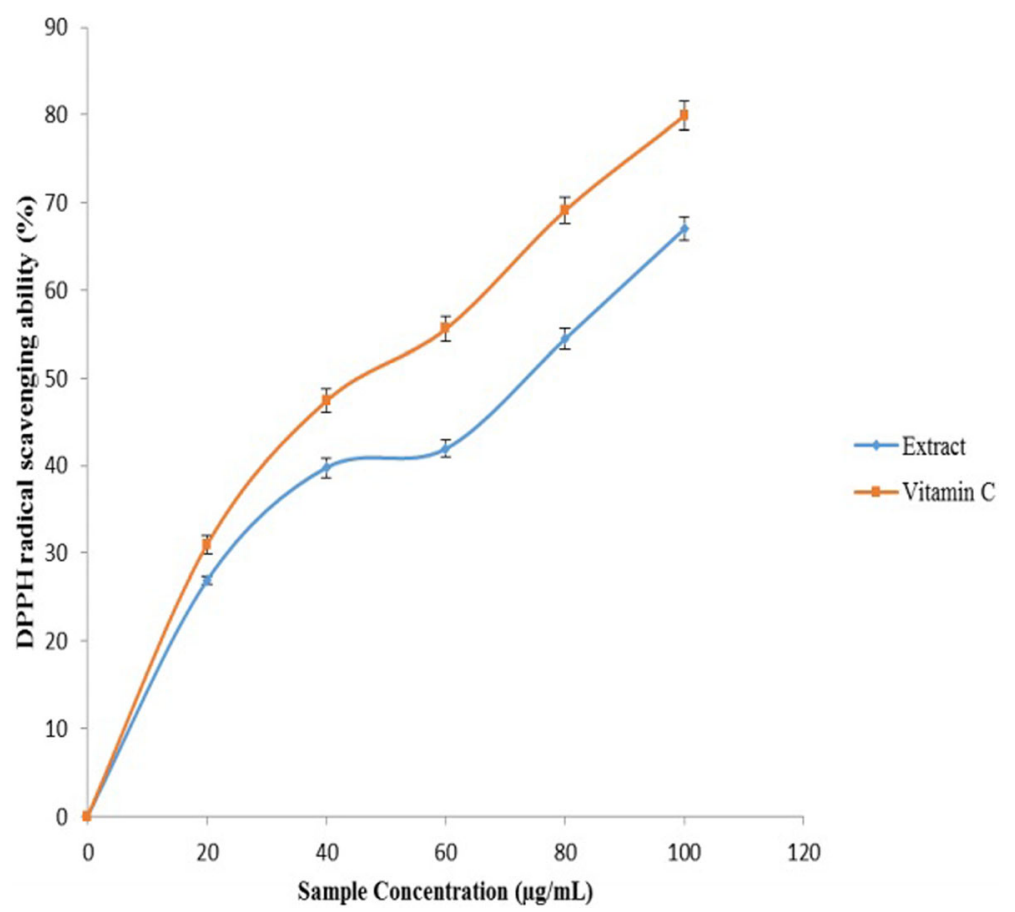

Fig. 5 DPPH radical scavenging ability of aqueous extract of $O$. gratissimum leaves and vitamin $C$

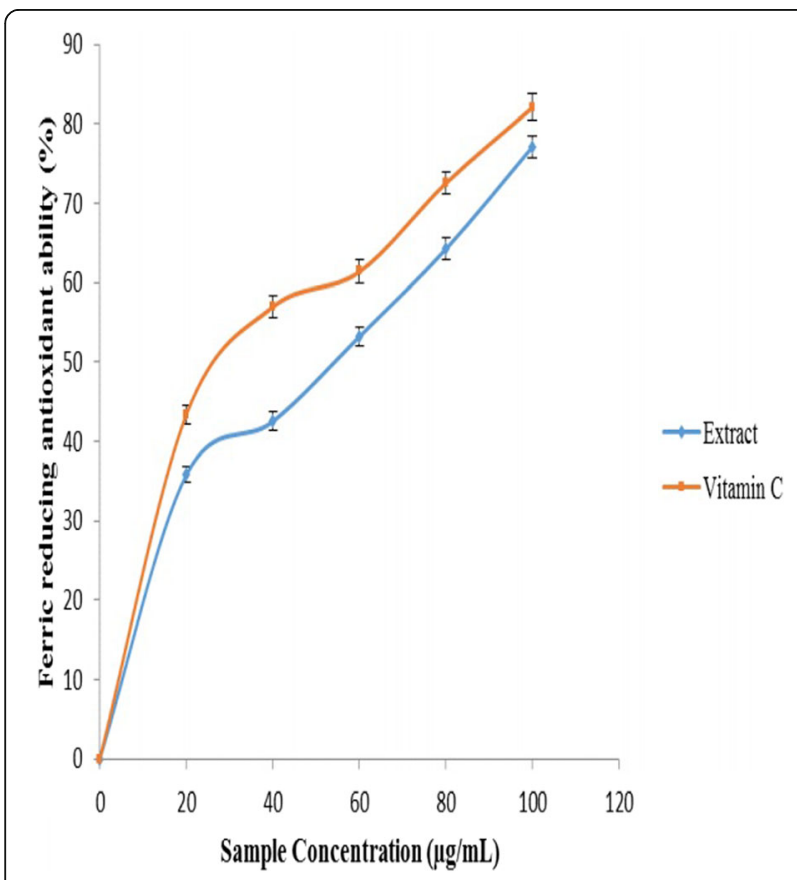

Fig. 6 Ferric reducing antioxidant property (FRAP) of aqueous extract of $O$. gratissimum leaves and vitamin $\mathrm{C}$ bioavailability of nitric oxide. Therefore, the ability of the extract to inhibit an arginase could be due to the presence of phenolics with arginase inhibitory properties which is supported by previous studies [8, 14, 49]. Our findings showed that aqueous extract from $O$. gratissimum inhibited arginase activity. Hence, the inhibitory activity observed could be linked to the presence of flavonoids and phenolic compounds like (-)-rutin, kaempferol, rosmarinic acid, caffeic acid and cichoric acid present in O. gratissimum extract reported by [50]. Moreover, Da Silva et al. [51] showed that flavonoids such as rutin are strong inhibitors of arginase enzyme.

Numerous studies have documented that cholinergic nerves in penile tissues must be able to release acetylcholine for the activation of $\mathrm{NO}$ production from L-arginine by nitric oxide synthase for better erectile function [7, 52-54]. The inhibition of the enzyme in penile and testicular tissue homogenates suggests that $O$. gratissimum could be a promising plant with beneficial potentials for the management of ED. Thus, inhibition of AChE by the extracts could be linked to the presence of flavonoids and phenolic compounds, which correlates with earlier studies that phenolic-rich plants could inhibit AChE $[8,9,55,56]$.

Angiotensin-II has been associated with hypertension a key causative agent of erectile dysfunction [8, 57]. Hence, the inhibition of ACE leading to the prevention of angiotensin- II synthesis may be a remedial target in the management of ED. Jin [58] documented that the 
considerable increase in NADPH oxidase activity, production of ROS and inhibition of nitric oxide synthase activity in penile and testicular tissues may be possible due to the elevated levels of angiotensin-II. Thus, hindering the production of angiotensin II could be helpful in the treatment of ED. Hence, these interactions could be due to the phenolic and flavonoids present in the leaves and disulphide bridge of the enzyme [57, 59, 60]. Moreover, flavonoids and phenols such as rutin, kaempferol, cichoric acid and caffeic acid present in the plant have been reported to be strong inhibitors of ACE activity $[61,62]$, and may be accounted for the greater inhibitory effect displayed by $O$. gratissimum. Thus, this study showed that aqueous extract from $O$. gratissimum inhibited ACE activity, reducing angiotensin II levels in erection organs.

Antioxidants achieve their protective role mainly by hindering the generation of radicals or by scavenging radical's production [21, 23, 63]. The mechanism of actions acknowledged influencing ferric reducing power as an antioxidant system is via proton transfer and electron transfer $[21,23,64]$. The reducing capacity of the extracts could also indicate potential antioxidant activities [65]. This reducing property could be because of the presence of polyphenols. Reducing power of O. gratissimum might have a therapeutic effect on erectile dysfunction.

In this study, $O$. gratissimum at the concentration tested revealed considerably ability to act as radical scavengers. This study revealed that aqueous extracts of $O$. gratissimum scavenged free radicals. The greater scavenging ability of the O. gratissimum may be accredited to the presence of secondary metabolites like phenolic acids and flavonoids [66]. All these radicals are involved in the pathogenesis of several disorders including erectile dysfunction. Hence, findings from this investigation shown that $O$. gratissimum extracts possessed antioxidant activity having reasonable scavenging activity towards the various forms of radicals studied $[67,68]$.

\section{Conclusion}

This study revealed that $O$. gratissimum extracts exhibited inhibitory properties on enzyme activities involved in erectile function and displayed free radical scavenging abilities which might be connected to their phenolic and flavonoids components. This indicates the erection stimulating properties of the plants and possible reasons for its use in the management of erectile dysfunction.

\footnotetext{
Abbreviations

ACE: Angiotensin-I-Converting Enzyme; AChE: Acetylcholinesterase; CAMP: Cyclic adenosine monophosphate; cGMP: Cyclic guanosine monophosphate; DPPH: 1,1-diphenyl-2-picryl-hydrazil; ED: Erectile dysfunction; eNOS: Endothelial tissue nitric oxide synthase; nNOS: Neuronal endothelial tissue nitric oxide synthase; NO: Nitric oxide; $O$. gratissimum: Ocimum gratissimum; $\mathrm{ONOO}_{2}$ : Peroxynitrite; PDE5: Phosphodiesterase-5; RAS: Renin-angiotensin system
}

\section{Acknowledgments}

The authors wish to thank the laboratory assistant for providing us with all necessary equipment's required for the study as well as the support by the South African Medical Research Council (SAMRC) through funding received from the South African National Treasury. Its contents are solely the responsibility of the authors and do not necessarily represent the official views of the South African Medical Research Council.

\section{Funding}

This work was financially supported by the South African Medical Research Council (SAMRC) through funding received from the South African National Treasury.

\section{Availability of data and materials}

The datasets used to analyze during this study are available from the corresponding author on reasonable request.

\section{Authors' contributions}

$\mathrm{OAO}$ and BOA conceived and designed the study, OEO and ORO performed the biological experiments, $\mathrm{ABO}, \mathrm{OOA}$ and $\mathrm{AA}$ carry out analysis and interpretation of data, BEO supervised the entire study. OAO, BOA, APK collaborated in the discussion of the results. $\mathrm{AAO}, \mathrm{ABO}, \mathrm{BOA}, \mathrm{BEO}, \mathrm{APK}$ wrote the manuscript and provided administrative support and critically revised the manuscript. All the authors have and approved the final manuscript.

\section{Competing interest}

Authors declare no competing interest whatsoever throughout the compilation of the manuscript. This manuscript is original and has not been submitted to another journal for possible publication.

Ethics approval and consent to participate

This study was done in compliance with the ethical committee of Afe Babalola University, Ado-Ekiti, Ekiti State, Nigeria.

Consent for publication

Not applicable.

\section{Publisher's Note}

Springer Nature remains neutral with regard to jurisdictional claims in published maps and institutional affiliations.

\section{Author details}

'Department of Biochemistry, Afe Babalola University, Ado-Ekiti, Nigeria. ${ }^{2}$ Department of Biochemistry, University of Ilorin, Ilorin, Nigeria. ${ }^{3}$ Department of Biochemistry, Ekiti State University, Ado-Ekiti, Nigeria. ${ }^{4}$ Department of Physiology, Afe Babalola University, Ado-Ekiti, Nigeria. ${ }^{5}$ Department of Medical Biochemistry, Afe Babalola University, Ado-Ekiti, Nigeria.

${ }^{6}$ Biotechnology and Structural Biology (BSB) Group, Department of Biochemistry and Microbiology, University of Zululand, KwaDlangezwa 3886, South Africa.

Received: 8 August 2018 Accepted: 12 March 2019

Published online: 19 March 2019

\section{References}

1. Gratzke C, Angulo J, Chitaley K, Dai YT, Kim NN, Paick JS, Simonsen U, Uckert S, Wespes E, Andersson KE, Lue TF, Stief CG Anatomy, physiology, and pathophysiology of erectile dysfunction. J Sex Med 2010; 7(1 Pt 2): 445-475.

2. NIH Consensus Conference. Impotence. NIH consensus development panel on impotence. JAMA. 1993;270(1):83-90.

3. Sasatomi K, Hiragata S, Miyazato M, Chancellor BM, Morris S, Yoshimura N. Nitric oxide mediated suppression of detrusor overactivity by arginase inhibitor in rats with chronic spinal cord injury. Urol. 2008;72:696-700.

4. Giugliano F, Maiorino M, Bellastella G, Gicchino M, Giugliano D, Esposito K. Determinants of erectile dysfunction in Type-2 diabetes. Int J Impot Res. 2010;22:204-9.

5. Lugnier C. Cyclic nucleotide phosphodiesterase (PDE) superfamily: a new target for the development of specific therapeutic agents. Pharmacol Ther. 2006;109:366-98. 
6. Goswami SK, Inamdar MN, Jamwal R, Dethe S. Effect of Cinnamomum cassia methanol extract and sildenafil on arginase and sexual function of young male Wistar rats. J Sex Med. 2014;11:1475-83.

7. Vargas VM, Torres D, Corona F, Vergara M, Gomez LE, Delgado-Lezama R, Cueva-Rolon R. Cholinergic facilitation of erection and ejaculation in spinal cord-transected rats. Int J Impot Res. 2004;16:86-90.

8. Akomolafe SF, Oboh G, Oyeleye SI, Boligon AA. Aqueous extract from Ficus capensis leaves inhibits key enzymes linked to erectile dysfunction and prevent oxidative stress in rats' penile tissue. NFS J. 2016:4:15-21.

9. Ojo OA, Ojo AB, Ajiboye BO, Oyinloye BE, Akinyemi AJ, Okesola MA, Boligon $A A$, de Campos MM. Chromatographic fingerprint analysis, antioxidant properties, and inhibition of cholinergic enzymes (acetylcholinesterase and butyrylcholinesterase) of phenolic extracts from Irvingia gabonensis (AubryLecomte ex O'Rorke) Baill bark. J Basic Clinl Physiol Pharmacol. 2018a;29(2): $217-24$

10. Andersson KE. Mechanisms of penile erection and basis for pharmacological treatment of erectile dysfunction. Pharmacol Rev. 2011;63:811-59.

11. Nunes KP, Webb RC. Mechanisms in Erectile Function and Dysfunction: An Overview, Erectile Dysfunction - Disease-Associated Mechanisms and Novel Insights into Therapy, Dr. Kenia Nunes (Ed.), InTech, 2012; DOI: https://doi. org/10.5772/39088

12. Bader M. Tissue renin-angiotensin-aldosterone systems: targets for pharmacological therapy. Annu Rev Pharmacol Toxicol. 2010;50:439-65.

13. Fraga-Silva RA, Montecucc F, Mach F, Santos RA, Stergiopulos N. Pathophysiological role of the renin-angiotensin system on erectile dysfunction. Eur J Clin Investig. 2013;43:978-85.

14. Oboh G, Ademiluyi AO, Ademosun AO, Olasehinde TA, Oyeleye SI, Boligon AA, Athayde ML. Phenolic extract from Moringa oleifera leaves inhibits key enzymes linked to erectile dysfunction and oxidative stress in rats' penile tissues. Biochem Res Int. 2015; [Epub ahead of print]; [1-8]. https://doi.org/ 10.1155/2015/175950.

15. Dorrance AM, Lewis RW, Mills TM, Mills TM. Captopril treatment reverses erectile dysfunction in male stroke prone spontaneously hypertensive rats. Int J Impot Res. 2002;14:494-7.

16. Haffner SM, Lehto S, Ronnemaa T, Pyorala K, Laakso M. Mortality from coronary heart disease in subjects with type-2 diabetes and in non-diabetic subjects with and without prior myocardial infarction. N Engl J Med. 1998; 339:229-34

17. Landete JM. Dietary intake of natural antioxidants: vitamins and polyphenols. Crit Rev Food Sci Nutr. 2013;53:706-21.

18. Ralebona N, Sewani-Rusike CR, Nkehchungag BN. Effects of ethanolic extract of Garcinia kola on sexual behaviour and sperm parameters in male Wistar rats. Afr J Pharma Pharmacol. 2012;6:1077-82.

19. Sulistiarini DL. Ocimum gratissimum L. In: Plant Resources of South-East Asia. No.19: Essential oils Plants. Oyen, P.A. and X. D. Nguyen (Eds.). Prosea Foundation, Bogor, Indonesia, 1999. p. 140-142.

20. Akinmoladun AC, Ibukun EO, Afor E, Obuotor EM, Farombi EO. Phytochemical constituent and antioxidant activity of extract from the leaves of Ocimum gratissimum. Sci Res Essay. 2007;2:163-6.

21. Ojo OA, Oloyede Ol, Olarewaju OI, Ojo AB, Ajiboye BO, Onikanni SA. In-Vitro antioxidant and free radical scavenging activities of Ocimum Gratissimum. Wr J Pharma Res. 2013a;2(6):1899-912.

22. Ojo OA, Oloyede Ol, Olarewaju OI, Ojo AB. In-Vitro antioxidant activity and estimation of Total phenolic content in ethyl acetate extract of Ocimum gratissimum. Pharmacologyonline. 2013b;3:37-44.

23. Ojo OA, Oloyede OI, Tugbobo OS, Olarewaju OI, Ojo AB. Antioxidant and inhibitory effect of scent leaf (Ocimum gratissimum) on $\mathrm{Fe}^{2+}$ and sodium nitroprusside induced lipid peroxidation in rat brain in vitro. Adv Biol Res. 2014a;8(1):8-17.

24. Dubey NK, Tiwari TN, Mandin DH, Andriamboavonjy JP, Chaumont A. Antifungal properties of Ocimum gratissimum essential oil (ethyl cinnamate chemotype). Fitoterapia. 2000;7:567-9.

25. Ojo OA, Oloyede Ol, Ajiboye BO, Olarewaju Ol. Effects of aqueous extract of Ocimum gratissimum on some hematological parameters of albino rats. Am Chem Sci J. 2014b;4(1):74-81.

26. Offiah VN, Chikwendu UA. Antidiarrhoeal effects of Ocimum gratissimum leaf extract in experimental animals. J Ethnopharmacol. 1999;68:327-30.

27. Ojo OA, Oloyede Ol, Olarewaju Ol, Akintayo CO, Fadaka AO. Effect of Ocimum gratissimum extract on the functional indices of selected tissues of male Wistar rats. Int J Appl Res Technol. 2014c;3(6):41-7.
28. Iweala EEJ, Obidoa O. Studies on some biochemical and histological changes associated with long term consumption of leaves of Ocimum gratissimum L. in male rats. Am J Food Technol. 2010;5:376-84.

29. Pande M, Pathak A. Effect of ethanolic extract of Ocimum gratissimum (ram tulsi) on sexual behavior in male mice. Int J Pharmaceutical Tech Res. 2009;1:468-73.

30. Singh R, Ali A, Gupta G, Semwal A, Jeyabalan G. Some medicinal plants with aphrodisiac potential: a current status. J Acute Dis. 2013;2:179-88.

31. Ebong PE, Efiong EE, Mgbeje BIA, Igile GO, Itam EH. Combined therapy of Moringa oleifera and Ocimum gratissimum reversed testicular damage in diabetic rats. Br J Med Med Res. 2014;4(11):2277-90.

32. Ojo OA, Oloyede Ol, Olarewaju Ol, Ojo AB, Ajiboye BO, Onikanni SA. Toxicity studies of the crude aqueous leaves extracts of Ocimum gratissimum in albino rats. IOSR J Environ Sci Toxicol Food Tech. 2013c;6(4):34-9.

33. Oboh G, Adebayo AA, Ademosun AO, Boligon AA. In vitro inhibition of phosphodiesterase- 5 and arginase activities from rat penile tissue by two Nigerian herbs (Hunteria umbellata and Anogeissus leiocarpus). J Basic Clin Physiol Pharmacol. 2017; [Epub ahead of print]. https://doi.org/10.1515/jbcpp-2016-0143.

34. Adefegha SA, Oboh G, Ejakpovi II, Oyeleye SI. Antioxidant and antidiabetic effects of gallic and protocatechuic acids: a structure-function perspective. Comp Clin Pathol. 2015;24:1579-85.

35. Cushman DW, Cheung HS. Spectrophotometric assay and properties of the angiotensin-converting enzyme of rabbit lung. Biochem Pharmacol. 1971; 20(7):1637-48.

36. Pulido R, Bravo L, Saura-Calixto F. Antioxidant activity of dietary polyphenols as determined by a modified ferric reducing/antioxidant power assay. J Agric Food Chem. 2000;48:396-402.

37. Gyamfi MA, Yonamine M, Aniya Y. Free-radical scavenging action of medicinal herbs from Ghana: Thonningia sanguinea on experimentallyinduced liver injuries. Gen Pharmacol. 1999:32:661-7.

38. Lue TF. Erectile dysfunction. N Engl J Med. 2000;342:1802-13.

39. Chuang T, Strauss JD, Murphy RA, Steers WD. A type-5 cGMP phosphodiesterase inhibitor specifically amplifies endogenous cGMP dependent relaxation in rabbit corpus cavernosum smooth muscle in vitro. J Urol. 1998;160:257-61.

40. Corbin JD. Mechanisms of action of PDE5 inhibition in erectile dysfunction. Int J Impot Res. 2004:16:4-7.

41. Saxena A, Prakash P, Porwal M, Sissodia N, Sharma P. Erectile dysfunction: a review and herbs used for its treatment. Int J Green Pharm. 2012:6:109-17.

42. Dell' Agli M, Bush PA, Dorey FJ. Polyphenols in orange peels (citrus species) enhances relaxation corpus cavernosum tissue: implications to erectile physiology and dysfunction. Can J Pharmacol. 2006;73:1714-26.

43. Dell' Agli M, Busciala A, Bossio E. Vascular effects of wine polyphenols. J Cardiovasc Res. 2005;63:593-602.

44. Chan EC, Pannangpetch P, Woodman OL. Relaxation to flavones and flavonols in rat isolated thoracic aorta: mechanism of action and structureactivity relationships. J Cardiovasc Pharmacol. 2000;35:326-33.

45. Kim JH, Bugaj LJ, Oh YJ, Bivalacqua TJ, Ryoo S, Soucy KG, Santhanam L, Webb A, Camara A, Sikka G, Nyhan D, Shoukas AA, llies M, Christianson DW, Champion HC, Berkowitz DE. Arginase inhibition restores NOS coupling and reverses endothelial dysfunction and vascular stiffness in old rats. J Appl Phys. 2009;107:1249-57.

46. Kim SW, Cuong TD, Hung TM, Ryoo S, Lee JH, Min BS. Arginase II inhibitory activity of flavonoid compounds from Scutellaria indica. Archives Pharmacal Res. 2013;36:922-9.

47. Segal R, Hannan JL, Liu X, Kutlu O, Burnett AL, Champion HC, Kim JH, Steppan D, Berkowitz DE, Bivalacqua TJ. Chronic Oral Administration of the Arginase Inhibitor 2(S)-amino-6-boronohexanoic acid (ABH) improves erectile function in aged rats. J Androl. 2012;33:1169-75.

48. Cassidy A, Franz M, Rimm EB. Dietary flavonoid intake and incidence of erectile dysfunction. Am J Clin Nutr. 2016;106:534-41.

49. Shin W, Cuong TD, Lee JH, Min B, Jeon BH, Lim HK, Ryoo S. 2011. Arginase inhibition by ethyl acetate extract of Caesalpinia sappan lignum contributes to activation of endothelial nitric oxide synthase. Korean J Physiol Pharmacol. 2011:15:123-8.

50. Salawu SO, Giaccherini C, Innocenti M, Vincieri FF, Akindahunsi AA, Mulinacci N. HPLC/DAD/MS characterisation and analysis of flavonoids and cynnamoil derivatives in four Nigerian green-leafy vegetables. Food Chem. 2009;115:1568-74.

51. Da Silva ER, Maquiaveli CDC, Magalhaes PP. The leishmanicidal flavonols quercetin and quercitrin target Leishmania (Leishmania) amazonensis arginase. Exp Parasitology. 2012;130(3):183-8. 
52. Hedlund $P$, Ny L, Alm P, Andersson KE. Cholinergic nerves in human corpus cavernosum and spongiosum contain nitric oxide synthase and heme oxygenase. J Urol. 2000;64:868-75.

53. Jung J, Jo HW, Kwon H, Jeong NY. Clinical neuroanatomy and neurotransmitter-mediated regulation of penile erection. Int Neurourology J. 2014;18:58-62.

54. Saenz de Tejada I, Blanco R, Goldstein I, Azadzoi K, de las Morenas A, Krane $\mathrm{RJ}$, et al. Cholinergic neurotransmission in human corpus cavernosum. I. Responses of isolated tissue. Am J Phys 1988; 254: 459-467.

55. Ojo OA, Ojo AB, Ajiboye BO, Olaiya O, Okesola MA, Boligon AA, de Campos MMA, Oyinloye BE, Kappo AP. HPLC-DAD fingerprinting analysis, antioxidant activities of Tithonia diversifolia (Hemsl.) a. Gray leaves and its inhibition of key enzymes linked to Alzheimer's disease. Toxicol Rep 2018b; 5: 585-592 https://doi.org/https://doi.org/10.1016/j.toxrep.2018.05.003.

56. Ojo OA, Ajiboye BO, Ojo AB, Olayide II, Akinyemi AJ, Fadaka AO, Adedeji EA, Boligon AA. Anraku de Campos MM. HPLC-DAD fingerprinting analysis, antioxidant activity of phenolic extracts from Blighia sapida bark and its inhibition of cholinergic enzymes linked to Alzheimer's disease. Jordan J Biol Sci. 2017;10(4):257-64.

57. John S, Schmieder RE. Potential mechanisms of impaired endothelial function in arterial hypertension and hypercholesterolemia. Curr Sci Inc Rep. 2003:5:199-207.

58. Jin L, Angiotensin II. Signaling and its implication in erectile dysfunction. J Sexual Med. 2009:6(3):302-10.

59. Park JK, Kim SZ, Kim SH, Park YK, Cho KW. Renin angiotensin system in rabbit corpus cavernosum: functional characterization of angiotensin II receptors. J Urol. 1997;158:653-8.

60. Ademiluyi AO, Oyeleye SI, Oboh G. Biological activities, antioxidant properties and phytoconstituents of essential oil from sweet basil (Ocimum basilicum L.) leaves. Comp Clin Pathol. 2015;25:169-1768.

61. Guerrero L, Castillo J, Quiñones M, Garcia-Vallvé S, Arola L, Pujadas G, Muguerza B. Inhibition of angiotensin-converting enzyme activity by flavonoids: structure-activity relationship studies. PLoS One. 2012;7:49493.

62. Shodehinde SA, Adefegha SA, Oboh G, Oyeleye SI, Olasehinde TA, Nwanna EE, Adedayo BC, Boligon AA. Phenolic composition and evaluation of methanol and aqueous extracts of bitter gourd (Momordica charantia $L$ ) leaves on angiotensin-l-converting enzyme and some pro-oxidant induced lipid peroxidation in vitro. J Evid-Based Complement Alternat Med. 2016;21:67-76.

63. Azadzoi KM, Siroky M. Oxidative stress and molecular reactions in arteriogenic erectile dysfunction. Chonnam Med J. 2009;45:1-8.

64. Dastmalchi K, Dorman HJD, Korsa M, Hiltunen R. Chemical composition of in vitro antioxidant evaluation of a water soluble mediavan balm (Dracocephalum moldavica L.) extract. Lebensmittel-Wissenschaft Technol. 2007:40:239-48.

65. Ojo OA, Afon AA, Ojo AB, Ajiboye BO, Oyinloye BE, Kappo AP. Inhibitory Effects of Solvent-Partitioned Fractions of Two Nigerian Herbs (Spondias mombin Linn. and Mangifera indica L.) on a-Amylase and a-Glucosidase. Antioxidants. 2018c;7(6):73

66. Ojo OA, Ajiboye BO, Imiere OD, Adeyonu O, Olayide II, Fadaka OA. Antioxidative properties of Blighia sapida K.D. Koenig stem bark extract and inhibitory effects on carbohydrate hydrolyzing enzymes associated with noninsulin dependent diabetes mellitus. Pharmacognosy J. 2018d;10(2):376-83.

67. Ajiboye BO, Ojo OA, Okesola MA, Oyinloye BE, Kappo AP. Ethyl acetate leaf fraction of Cnidoscolus aconitifolius (mill.) I. M. Johnst: antioxidant potential, inhibitory activities of key enzymes on carbohydrate metabolism, cholinergic, monoaminergic, purinergic and chemical fingerprinting. Int J Food Prop. 2018a;21(1):1697-715.

68. Ajiboye BO, Ojo OA, Okesola MA, Akinyemi AJ, Talabi JY, Idowu OT, Fadaka $\mathrm{AO}$, Boligon AA, de Campos MMA. In vitro antioxidant activities and inhibitory effects of phenolic extract of Senecio biafrae (Oliv and Hiern) against key enzymes linked with type II diabetes mellitus and Alzheimer's disease. Food Science and Nutrition. 2018b;6(7):1803-10.

Ready to submit your research? Choose BMC and benefit from:

- fast, convenient online submission

- thorough peer review by experienced researchers in your field

- rapid publication on acceptance

- support for research data, including large and complex data types

- gold Open Access which fosters wider collaboration and increased citations

- maximum visibility for your research: over $100 \mathrm{M}$ website views per year

At $\mathrm{BMC}$, research is always in progress.

Learn more biomedcentral.com/submissions 